\title{
Autoantibodies against the prion protein in individuals with PRNP mutations
}

Karl Frontzek, MD, PhD, Manfredi Carta, MD, Marco Losa, MD, Mirka Epskamp, MSc, Georg Meisl, PhD, Alice Anane, ND, Jean-Philippe Brandel, MD, Ulrike Camenisch, PhD, Joaquín Castilla, PhD, Stéphane Haïk, MD, PhD, Tuomas Knowles, PhD, Ewald Lindner, MD, Andreas Lutterotti, MD, Eric Vallabh Minikel, PhD, Ignazio Roiter, MD, Jiri G. Safar, MD, Raquel Sanchez-Valle, MD, PhD, Dana Žáková, PhD, Simone Hornemann, PhD, and Adriano Aguzzi, MD, PhD, for the THAUTAN-MC Study Group

Neurology ${ }^{\circledR}$ 2020;95:e2028-e2037. doi:10.1212/WNL.0000000000009183

\author{
Correspondence \\ Dr. Frontzek \\ karl.frontzek@usz.ch \\ or Dr. Aguzzi \\ adriano.aguzzi@usz.ch
}

\begin{abstract}
Objective

To determine whether naturally occurring autoantibodies against the prion protein are present in individuals with genetic prion disease mutations and controls, and if so, whether they are protective against prion disease.
\end{abstract}

\section{Methods}

In this case-control study, we collected 124 blood samples from individuals with a variety of pathogenic $P R N P$ mutations and 78 control individuals with a positive family history of genetic prion disease but lacking disease-associated $P R N P$ mutations. Antibody reactivity was measured using an indirect ELISA for the detection of human immunoglobulin $\mathrm{G}_{1-4}$ antibodies against wild-type human prion protein. Multivariate linear regression models were constructed to analyze differences in autoantibody reactivity between (1) PRNP mutation carriers vs controls and (2) asymptomatic vs symptomatic PRNP mutation carriers. Robustness of results was examined in matched cohorts.

\section{Results}

We found that antibody reactivity was present in a subset of both PRNP mutation carriers and controls. Autoantibody levels were not influenced by PRNP mutation status or clinical manifestation of prion disease. Post hoc analyses showed anti-PrP $\mathrm{P}^{\mathrm{C}}$ autoantibody titers to be independent of personal history of autoimmune disease and other immunologic disorders, as well as PRNP codon 129 polymorphism.

\section{Conclusions}

Pathogenic $P R N P$ variants do not notably stimulate antibody-mediated anti-PrP ${ }^{\mathrm{C}}$ immunity. Anti-PrP ${ }^{\mathrm{C}}$ immunoglobulin $\mathrm{G}$ autoantibodies are not associated with the onset of prion disease. The presence of anti-PrP ${ }^{\mathrm{C}}$ autoantibodies in the general population without any diseasespecific association suggests that relatively high titers of naturally occurring antibodies are welltolerated.

\section{Clinicaltrials.gov identifier NCT02837705.}

From the Institute of Neuropathology (K.F., M.C., M.L., M.E., S. Hornemann, A.A.), Institute of Surgical Pathology (U.C.), and Department of Neurology, Neuroimmunology and MS Research (NIMS) (A.L.), University of Zurich, Switzerland; Department of Chemistry (G.M., T.K.), University of Cambridge, UK; CJD Foundation Israel (A.A.), Pardes Hanna; ICM (J.-P.B.), Salpêtrière Hospital, Sorbonne University, Paris, France; CIC bioGUNE and IKERBASQUE (J.C.), Basque Foundation for Science, Bizkaia, Spain; Sorbonne University (S. Haïk), ICM, Salpêtrière Hospital, Paris, France; Ophthalmology Division (E.L.), University of Graz, Austria; Broad Institute (E.V.M.), Cambridge, MA; Treviso Hospital (I.R.), Italy; Department of Pathology, Neurology, and National Prion Disease Pathology Surveillance Center (J.G.S.), Case Western Reserve University, Cleveland, OH; Alzheimer's Disease and Other Cognitive Disorders Unit (R.S.-V.), Hospital Clinic, IDIBAPS, University of Barcelona, Spain; and Department of Prion Diseases (D.Ž.), Slovak Medical University, Bratislava, Slovakia.

Go to Neurology.org/N for full disclosures. Funding information and disclosures deemed relevant by the authors, if any, are provided at the end of the article. 


\section{Glossary}

CJD = Creutzfeldt-Jakob disease; EBNA = Epstein-Barr nuclear antigen; FT = flexible tail; GD = globular domain; $\mathbf{g P r D}=$ genetic prion diseases; GSS = Gerstmann-Sträussler-Scheinker; sCJD = sporadic Creutzfeldt-Jakob disease.

Prion diseases are diseases of the CNS that not only occur as sporadic and transmissible forms, but can also be transmitted through the germ line as autosomal dominant traits. ${ }^{1}$ Genetic prion diseases ( $\mathrm{gPrDs}$ ) account for $\sim 10 \%-15 \%$ of all prion diseases and are characterized by pathogenic, nonsynonymous mutations of the human prion protein gene PRNP. ${ }^{2}$ The most prevalent human prion disease, sporadic Creutzfeldt-Jakob disease (sCJD), is characterized by a rapidly progressive dementia and a short survival time (usually $<1$ year) from clinical onset. ${ }^{3}$ In contrast, $P R N P$ mutation carriers often present with atypical phenotypes; for example, long survival rates can be observed in Gerstmann-SträusslerScheinker (GSS) disease. ${ }^{4}$

The cellular prion protein $\mathrm{PrP}^{\mathrm{C}}$ consists of an unstructured flexible tail (FT) on its $\mathrm{N}$-terminal end and a C-terminal globular domain (GD). ${ }^{5}$ We showed in 2001 that humoral immunity against $\operatorname{PrP}^{\mathrm{C}}$ can protect against prion neuroinvasion. ${ }^{6}$ Antibodies against the $\mathrm{FT}$ of $\mathrm{PrP}^{\mathrm{C}}$, or removal of amino acid residues from the FT, abrogate the neurotoxic effects of anti-PrP $\mathrm{P}^{\mathrm{C}}$-GD antibodies and reduce the toxicity of bona fide prions. ${ }^{7,8}$ Naturally occurring PrP antibodies may exist in the general population: for instance, reactivity against a 21-residue $\mathrm{PrP}$ peptide was observed in commercial pooled immunoglobulin, ${ }^{9}$ and a unique blood group has been observed in individuals homozygous for the E219K polymorphism. ${ }^{10}$

Clinical trials have yet to deliver an effective antiprion agent. ${ }^{11-14}$ An ongoing clinical study involves the administration of PRN100, a humanized antibody against $\mathrm{PrP}^{\mathrm{C}}-\mathrm{GD}$, to individuals with Creutzfeldt-Jakob disease (CJD) ${ }^{15}$ There is much hope that this trial will be successful, but the murine counterpart of PRN100, ICSM18, exhibits an on-target, dosedependent toxicity, and whether a therapeutic window exists has not yet been established. ${ }^{16-18}$

The frequency of PRNP missense variants exceeds the reported $\mathrm{gPrD}$ prevalence, suggesting a spectrum of disease penetrance in $\mathrm{gPrDs}$ rather than complete penetrance of nonsynonymous PRNP mutations. ${ }^{19}$ The mechanisms by which these mutations induce disease are largely unclear. The majority of structural studies on human $\operatorname{PrP}^{\mathrm{C}}$ variants linked to $\mathrm{gPrD}$ failed to identify consistent effects on global protein stability. ${ }^{20}$ Age at onset in $\mathrm{gPrD}$ is highly variable, and typically middle age or older, which might suggest that a protective mechanism guards some individuals against the prion protein-induced toxicity. ${ }^{2}$ We hypothesized that subtle conformational alterations of pathogenic $\operatorname{PrP}^{\mathrm{C}}$ variants could stochastically generate immunogenic neoepitopes, which in turn might elicit a protective humoral anti-PrP ${ }^{\mathrm{C}}$ immune response. We therefore conducted an extensive search for such autoantibodies in individuals carrying pathogenic $P R N P$ mutations, and in unaffected relatives as controls.

\section{Methods}

\section{Standard protocol approvals, registrations, and patient consents}

The Cantonal Ethics Committee of the Canton of Zurich approved this study (permit no. KEK-ZH Nr.2015-0514). This trial was registered at clinicaltrials.gov (no. NCT02837705). The protocol for this study was approved by the institutional review board at each participating institution with the University of Zurich being the lead regulatory site. Written informed patient consent was received by all individuals participating in this study.

\section{Human participants and study design}

We defined PRNP mutation carriers as individuals with a nonsynonymous mutation in the open reading frame of the $P R N P$ gene that was previously reported to be pathogenic. ${ }^{2}$ Between September 2015 and October 2018, we contacted both international patient organizations as well as national prion disease reference centers for further reuse of existing blood samples. Individuals at any age with a confirmed PRNP mutation were considered eligible for this study. Individuals with a confirmed PRNP mutation in a blood relative who did not undergo PRNP sequencing prior to enrollment in this study were also considered eligible if they gave consent for $P R N P$ sequencing. Blood samples without information on age or sex were excluded from further analysis. PRNP wild-type individuals with neurologic or psychiatric symptoms indicative of $\mathrm{gPrD}$ were excluded from the study. ${ }^{21}$ Clinical manifestation of $\mathrm{gPrD}$ was defined as presence of both a pathogenic PRNP mutation and PrD-typical symptoms. ${ }^{21}$ The latter were assessed by clinical examination and neuropsychological assessment, in some cases complemented by ancillary tests such as presence of 14-3-3 proteins in CSF, realtime quaking-induced conversion assays, EEG, and MRI. ${ }^{22}$ Personal history of autoimmune disease and other immunologic disorders could be obtained in 141 participants. A detailed description of the patient cohort is given in table 1 . For sensitivity analysis, cases and controls were matched on age ( \pm 5 years), sex, and blood sample type (i.e., serum or plasma).

\section{PRNP genotyping}

PRNP genotyping was performed using a modified version of the DNeasy Blood \& Tissue Kit (Qiagen, Venlo, the Netherlands). Twenty microliters of proteinase $\mathrm{K}(600 \mathrm{mAU} / \mathrm{mL})$ and $200 \mu \mathrm{L}$ of $5 \mathrm{M}$ guanidine hydrochloride with $1 \%$ Triton- 
Table 1 Baseline characteristics of the unmatched cohort

\begin{tabular}{|c|c|c|c|c|}
\hline & PRNP mutation carriers, $\mathrm{n}(\%)$ & PRNP wild-type, n (\%) & Missing data, n (\%) & $p$ Value \\
\hline Individuals enrolled, $\mathbf{n}$ & 124 & 78 & & \\
\hline \multicolumn{5}{|l|}{ Age, y } \\
\hline Mean & 49.3 & 42.8 & & 0.004 \\
\hline SD & 16.5 & 13.9 & & \\
\hline Autoimmune disease $^{a}$ & $8 / 141(5.7)$ & & $61(30.2)$ & 0.49 \\
\hline Female sex & $80(64.5)$ & $37(47.4)$ & & 0.02 \\
\hline 14-3-3 protein in CSF & & & $80(39.6)^{b}$ & NA \\
\hline Test performed & $17 / 63(27.0)$ & $0 / 59(0.0)$ & & \\
\hline Positive 14-3-3 & $8 / 17(47.0)$ & NA & & \\
\hline Codon 129 polymorphism & & & $20(9.9)^{c}$ & $<0.0001$ \\
\hline Met/Met & 69/121 (57.0) & 15/61 (24.6) & & \\
\hline Met/Val & $50 / 121(41.3)$ & $37 / 61(60.7)$ & & \\
\hline Val/Val & $2 / 121(1.7)$ & $9 / 61(14.8)$ & & \\
\hline \multicolumn{5}{|l|}{ Pathogenic PRNP mutation } \\
\hline P102L & $3(2.4)$ & NA & & \\
\hline D178N & $37(29.8)$ & NA & & \\
\hline E200K & $77(62.1)$ & NA & & \\
\hline V210I & $2(1.6)$ & NA & & \\
\hline Unique & $5(4.0)$ & NA & & \\
\hline \multicolumn{5}{|l|}{ Blood storage $^{d}$} \\
\hline Plasma & $98(79.0)$ & $70(89.7)$ & & \\
\hline Serum & $26(21.0)$ & $8(10.3)$ & & \\
\hline
\end{tabular}

a Due to few events of autoimmune disease, we pooled genotypes to eliminate possible identification. $p$ Value compares numbers of individuals with or without autoimmune disease in PRNP mutation carriers and wild-type PRNP.

${ }^{\mathrm{b}}$ Missing values: 61 PRNP mutation carriers, 19 PRNP wild-type.

'Missing values: 3 PRNP mutation carriers, 17 PRNP wild-type.

${ }^{d}$ Unique $(n=1)$ mutations: D178N/N171S, V180I, T183A, F198S, E200G.

$\mathrm{X} 100$ at $\mathrm{pH}=5.0$ were added to $200 \mu \mathrm{L}$ of anticoagulated blood, vortexed thoroughly, and incubated for 24 hours at room temperature. Two hundred microliters EtOH (96\%-100\%) was added to the reaction and the rest of the DNA purification was performed according to the manufacturer's guidelines. The primer pair PRNP up and PRNP low (table e-1, doi.org/10.5061/dryad.08kprr4xk) was used in combination with Q5 high-fidelity DNA polymerase (New England Biolabs, Ipswich, MA) to amplify the open reading frame from exon 2 of PRNP. Sanger sequencing was performed at the Department of Molecular Pathology (Institute of Surgical Pathology, University Hospital Zurich) using 4 different sequencing primers (PRNP_up, PRNP_up2, PRNP_low, PRNP_low2; table e-1, doi.org/10.5061/dryad. $08 \mathrm{kprr} 4 \mathrm{xk}$ ). Sequencing traces were aligned to reference DNA from the Reference Sequence Database (RefSeq at National Center of Biotechnology Information, Bethesda,
MD) using CLC Main Workbench (Qiagen) and packages sangerseqr ${ }^{23}$ and DECIPHER ${ }^{24}$ for Bioconductor ${ }^{25}$ in $\mathrm{R}$.

\section{Statistical analyses}

We performed a priori testing of anti-PrP ${ }^{\mathrm{C}}$ autoantibody reactivity for the following hypotheses: (1) differences in anti-PrP ${ }^{\mathrm{C}}$ autoantibody reactivity between PRNP mutation carriers and $P R N P$ wild-type individuals and (2) differences in anti-PrP ${ }^{\mathrm{C}}$ autoantibody reactivity between PRNP mutation carriers showing clinical signs of prion diseases and those without. All other analyses were performed post hoc. We used already established predictors of autoimmune disease such as age ${ }^{26}$ and $\operatorname{sex}^{27}$ as well as storage conditions known to affect antibody responses such as presence of coagulation factors $^{28}$ as covariates in our multivariate regression model. Using the purposeful selection of covariates method as described previously, ${ }^{29}$ effects of covariates on autoantibody titers were 
tested by bivariate linear regression analyses using the Wald test and included for multivariate testing at a $p$ value cutoff point of 0.25 . In the multivariate model, covariates were removed if they were nonsignificant at the 0.1 a level or not a confounder, as determined by a change in the remaining parameter estimate greater than $20 \%$ as compared to the full model. PRNP mutation status, clinical signs of prion disease, and PRNP codon 129 polymorphism were added after establishment of significant confounders. In matched cohorts, multivariate models were adjusted for matching factors.

All values are given as average \pm SD unless mentioned otherwise. For analysis, autoantibody titers were $\log _{10}$-transformed, and reported $\beta$ coefficients and confidence intervals represent back-transformed values. Normality was tested using the D'Agostino-Pearson normality test. For values following a Gaussian distribution, differences between 2 groups were compared using 2-tailed Student $t$ test. For not normally distributed values, Mann-Whitney $U$ test was used for comparison of 2 groups. For comparison of categorical variables, Fisher exact test and $\chi^{2}$ test were used for comparison of 2 and more than 2 groups, respectively. Pearson correlation coefficient was computed for data sampled from Gaussian distributions and Spearman $\rho$ for those sampled from nonGaussian distributions. Matching of cases and controls was done using the find.matches function from the Hmisc package in $\mathrm{R}$. We used $\mathrm{Im}$ for $\mathrm{R}$ for linear regression analysis. Python and $\mathrm{R}$ were used for statistical analysis and data visualization was performed using Prism 7 (GraphPad).

\section{Data availability}

The study participants, if they have not undergone predictive testing themselves, participated under the condition of not knowing their PRNP genotype. Due to the relatively small sample size and risk of de-identification, all raw study data involving human participants were made available to the editors and reviewers but will not be made available publicly. Supplementary data, as well as DNA sequences of gene blocks used for construction of humanized antibodies and human $\operatorname{PrP}^{\mathrm{C}}$-AviTag, are available at Dryad (doi.org/10.5061/dryad. 08kprr4xk).

\section{Results}

\section{Description of the cohort}

We received blood samples and clinical information from a total of 241 individuals and selected 202 unmatched cases and controls for this analysis (figure 1). To test the robustness of our results, we matched 64 cases on 64 controls based on age ( \pm 5 years), sex, and blood storage conditions (i.e., serum/ plasma; table e-2, doi.org/10.5061/dryad.08kprr4xk). Anti$\operatorname{PrP}^{\mathrm{C}}$ autoantibody reactivity was measured by a sandwich ELISA; a description of the assay is provided in extended text and figures e-1 and e-2 (doi.org/10.5061/dryad.08kprr4xk). Briefly, blood samples were diluted over a range of $>2$ logs and bound autoantibodies were detected with anti-human IgG antibodies. Antibody titers are expressed as negative common logarithm of the half-maximal effective concentration (figure $\mathrm{e}-1 \mathrm{E})$. Anti-PrP $\mathrm{P}^{\mathrm{C}}$ antibody reactivity was independent of serum IgG levels (Spearman $\rho=0.07, p=0.69$; figure $2 \mathrm{~A}$ ). The age of probands did not influence the IgG levels (Pearson $r=$ $0.33, p=0.16$ ). To confirm our ability to detect human antibodies against specific targets, we tested a subset of individuals for the presence of IgG against EBNA. A total of 4/5 $P R N P^{\mathrm{WT}}$ and $16 / 16 P R N P^{\mathrm{Mut}}$ individuals tested positive (corresponding to $95 \%$ positive individuals), in line with antiEBNA IgG seroprevalence in the general population (figure $2 \mathrm{~B}) .{ }^{30}$

\section{Prevalence of anti-PrPC autoantibodies in PRNP mutation carriers}

The presence of coagulation factors (e.g., plasma instead of serum), and possibly age, but not female sex were associated with anti-PrP $\mathrm{P}^{\mathrm{C}}$ autoantibody reactivity in bivariate and multivariate analyses (table 2). ${ }^{29}$ We henceforth adjusted all analyses for age and presence of coagulation factors. Presence or absence of a pathogenic $P R N P$ mutation was not associated with significant changes in anti- $\mathrm{PrP}^{\mathrm{C}}$ autoantibody reactivity (table 3). In addition, we matched 62 cases and controls on age ( \pm 5 years), sex, and blood sample type ${ }^{26-28}$ (table e-2, doi. org/10.5061/dryad.08kprr4xk). As with the unmatched cohort, $P R N P$ mutation did not significantly influence anti- $\operatorname{PrP}^{\mathrm{C}}$ autoantibody titers in multivariate linear regression adjusted for matching factors (table e-2).

We then tested whether anti-PrP ${ }^{C}$ autoantibody response was associated with symptoms of prion disease. Presence or absence of clinical signs was reported by 122 PRNP mutation carriers (out of a total of 124 enrolled): 76 (62.3\%) were asymptomatic carriers whereas $46(37.7 \%)$ presented with clinically apparent disease. Detailed clinical data were available in 14 cases. The most common clinical presentations entailed cerebellar signs $(n=12[85.7 \%])$ and dementia $(n=11[78.6 \%])$. Status of $14-3-3$ protein in CSF, albeit a poor predictor of $\mathrm{gPrD},{ }^{31}$ was provided by 121 study participants. Seventeen individuals (all PRNP mutation carriers with clinically apparent disease) were tested, with 8 (47.1\%) testing positive, in line with previous findings. ${ }^{31}$ Presence of prion-specific symptoms was not associated with alterations in anti-PrP ${ }^{\mathrm{C}}$ autoantibodies in an unmatched cohort (table 3). This was confirmed in an analysis of a cohort consisting of 24 symptomatic PRNP mutation carriers and 24 asymptomatic PRNP mutation carriers matched on PRNP mutation, age, and sample type (table e-2, doi.org/10. 5061/dryad.08kprr4xk).

\section{Post hoc subgroup analyses on the association of anti-PrP ${ }^{C}$ autoantibodies with specific PrP ${ }^{C}$ mutations, $\operatorname{PrP}^{\mathrm{C}}$ p.129 polymorphism, and autoimmune disease and other immunologic disorders}

We analyzed the effects of $P R N P$ mutations that were present at least 5 times in the study population, namely D178N and 


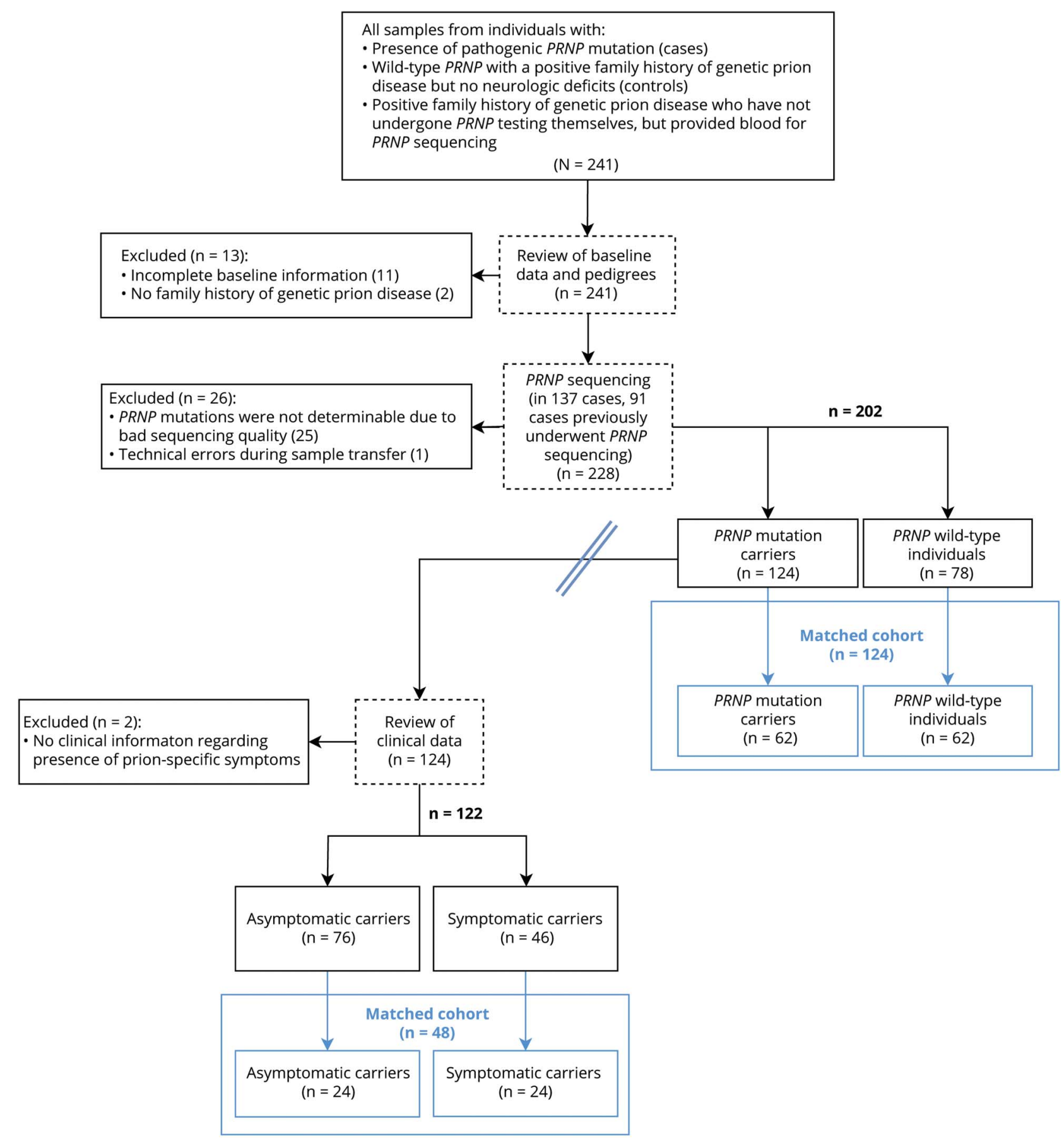

Double line indicates cohorts selected for comparison of anti-PrP ${ }^{C}$ autoantibody titers from individuals carrying wild-type or mutated $P R N P$ alleles (right of double line) and cohort selected for comparing anti-PrPC autoantibody titers of symptomatic vs asymptomatic mutation carriers (left of double line). Blue boxes indicate matched cohorts.

E200K, on anti-PrP ${ }^{\mathrm{C}}$ autoantibody titers: individuals with D178N mutations showed a significant trend towards lower autoantibody titers in bivariate analysis (table 3). This finding, however, was not significant after adjusting for age and sample type (table 3). E200K mutation carriers did not show significant changes in autoantibody reactivity (table 3 ). The methionine/valine polymorphism at codon 129 of the human PRNP gene was reported to affect the susceptibility to prion diseases. ${ }^{32}$ Information on p.129 polymorphism was available in 182 study participants: 84 (46.2\%) were homozygous for methionine (p.129MM), 87 (47.8\%) p.129MV, and 11 (6.0\%) p.129VV. None of the polymorphisms significantly altered autoantibody response to $\operatorname{PrP}^{\mathrm{C}}$ in a post hoc analysis (table 4). In D178N carriers, the clinical phenotype was suggested to be dependent on the PRNP cis c.129 polymorphism: methionine was associated with fatal familial 
Figure 2 Correlation of anti-PrP $\mathrm{P}^{\mathrm{C}}$ autoantibody reactivity with total immunoglobulin G (IgG) levels, IgG anti-Epstein-Barr virus (EBV) autoantibodies, and change of autoantibody titers over time

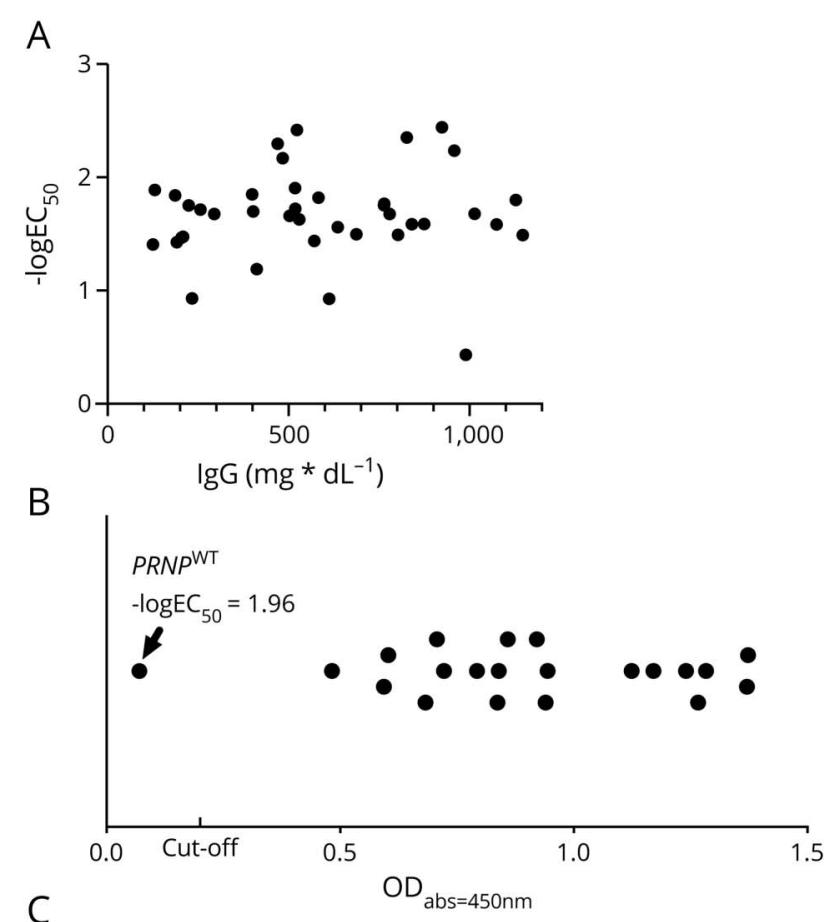

C

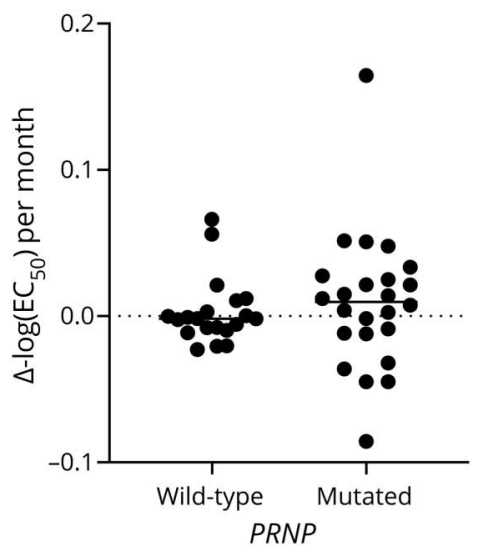

(A) Correlation of total IgG with anti-PrPC autoantibody titers. (B) Qualitative assessment of anti-Epstein-Barr nuclear antigen (EBNA) IgG antibodies in blood shows 1 PRNP $P^{\mathrm{WT}}$ individual without detectable anti-EBNA IgG antibodies. Cutoff: $O D_{a b s}=450 \mathrm{~nm}$ (optical density at absorbance $\lambda=450 \mathrm{~nm}$ ) $=$ 0.2 according to the manufacturer's guidelines. (C) In 2 subsequent blood drawings, mean change in antibody titers per year is stable and similar between PRNP mutation and wild-type carriers, but variance is larger in PRNP mutation carriers.

insomnia and valine with familial CJD, ${ }^{2}$ although this association may not be universal. ${ }^{33,34}$ In our cohort, 28 patients could be unambiguously identified as D178N cis $129 \mathrm{M}$ and 5 patients as D178N_cis129V. No differences in mean antibody reactivity were seen between those 2 groups (table 4 ).

Co-occurrence of multiple autoimmune diseases is a commonly observed phenomenon. ${ }^{35}$ In order to test the influence of preexisting autoimmune diseases on anti-PrP ${ }^{\mathrm{C}}$
Table 2 Age and lack of coagulation factors in blood (e.g., serum probes), but not sex, are significantly associated with anti-PrPC autoantibody reactivity

\begin{tabular}{llll}
\hline Risk factor & $\begin{array}{l}\boldsymbol{\beta} \\
\text { coefficient }\end{array}$ & $\begin{array}{l}\text { 95\% confidence } \\
\text { interval }\end{array}$ & $\begin{array}{l}\boldsymbol{p} \\
\text { Value }\end{array}$ \\
\hline Bivariate analyses & & & \\
\hline Age & 0.990 & $0.982-0.998$ & 0.05 \\
\hline Female sex & 1.14 & $0.86-1.48$ & 0.42 \\
\hline $\begin{array}{l}\text { Plasma instead of } \\
\text { serum }\end{array}$ & 1.84 & $1.31-2.58$ & 0.004 \\
\hline
\end{tabular}

Multivariate analysis:

model A

\begin{tabular}{llll}
\hline Age & 0.990 & $0.982-0.997$ & 0.032 \\
\hline $\begin{array}{l}\text { Plasma instead of } \\
\text { serum }\end{array}$ & 1.88 & $1.34-2.63$ & 0.002 \\
\hline
\end{tabular}

Multivariate analysis:

model B

\begin{tabular}{llll}
\hline Age & 0.989 & $0.981-0.997$ & 0.026 \\
\hline Female sex & 1.16 & $0.90-1.50$ & 0.35 \\
\hline $\begin{array}{l}\text { Plasma instead of } \\
\text { serum }\end{array}$ & 1.86 & $1.33-2.61$ & 0.003 \\
\hline
\end{tabular}

Due to lack of confounding effects of sex in multivariate model B, all further analyses were adjusted for blood sample type (serum/plasma) and age.

autoantibody titers, we searched clinical reports of study participants for presence of autoimmune disease and other immunologic disorders. We were able to retrieve this information in $141(69.8 \%)$ cases: 8 individuals were diagnosed with autoimmune disease, namely Hashimoto thyroiditis $(n=3)$, Graves disease $(n=1)$, monoclonal gammopathy of unknown significance $(n=1)$, multiple sclerosis $(\mathrm{n}=1)$, psoriasis $(\mathrm{n}=1)$, and rheumatoid arthritis $(\mathrm{n}=1)$. Multivariate linear regression analysis adjusted for age, sex, and type of blood sample did not show a significant association of autoimmune disease with anti-PrP $\mathrm{P}^{\mathrm{C}}$ autoantibody titers (table 4).

\section{Temporal evolution of anti-PrPC autoantibodies}

Forty-four individuals (21.8\%) donated blood multiple times, several months apart, on which we performed a post hoc time course analysis. PRNP wild-type individuals were observed over a longer time period compared to PRNP mutation carriers $(17 \pm 1.78$ months vs $10 \pm 6.21$ months, $p$ $\left.=1.42 \times 10^{-5}\right)$. PRNP mutation carriers showed larger variability in autoantibody titers; mean proportional change per year, however, was similar across groups $(p=0.23)$ and was overall negligible between 2 blood drawings (113.2 $\pm 61.44 \%$ per year in PRNP mutation carriers vs $99.95 \pm 17.22 \%$ per year in PRNP wild-type individuals, figure 2C). None of the PRNP mutation carriers tested in this time course analysis exhibited clinical signs of prion disease. 
Table 3 Effect of $P R N P$ mutation status on anti-PrPC autoantibody reactivity

\begin{tabular}{llll}
\hline Risk factor & $\begin{array}{l}\boldsymbol{\beta} \\
\text { coefficient }\end{array}$ & $\begin{array}{l}\text { 95\% confidence } \\
\text { interval }\end{array}$ & $\begin{array}{l}\boldsymbol{p} \\
\text { Value }\end{array}$ \\
\hline PRNP mutation (all) & & & \\
\hline Crude & 0.81 & $0.62-1.05$ & 0.19 \\
\hline Adjusted & 0.92 & $0.70-1.20$ & 0.61 \\
\hline PRNP D178N mutation & & & \\
\hline Crude & 0.61 & $0.44-0.86$ & 0.02 \\
\hline Adjusted & 0.75 & $0.53-1.06$ & 0.17 \\
\hline PRNP E200K mutation & & & \\
\hline Crude & 1.16 & $0.89-1.16$ & 0.36 \\
\hline Adjusted & 1.18 & $0.91-1.54$ & 0.30 \\
\hline $\begin{array}{l}\text { Clinical signs of prion } \\
\text { disease }\end{array}$ & & & \\
\hline Crude & 0.90 & $0.59-1.38$ & 0.64 \\
\hline Adjusted & 0.94 & $0.61-1.46$ & 0.79 \\
\hline
\end{tabular}

\section{Discussion}

The diagnosis of a disease-associated PRNP mutation is a fateful and often devastating event for individuals carrying such mutations. The clinical penetrance of PRNP mutations can be very high, and no disease-modifying therapy is available. $^{2}$ Clinical signs of familial prion disease typically erupt in late adulthood, although carriers arguably produce the mutated protein from the first day of their life. ${ }^{5}$ There are at least 2 scenarios that may account for this phenomenon: (1) the pathogenic mutations may slightly destabilize $\operatorname{PrP}^{\mathrm{C}}$, thereby infinitesimally increasing the probability of pathologic aggregation; or (2) the pathogenic conformation of $\operatorname{PrP}^{\mathrm{C}}$ is attained early on, but the body's defenses stave off its consequences for decades.

In the case of scenario 1, extensive structural studies on pathogenic $\mathrm{PrP}^{\mathrm{C}}$ variants failed to reveal major structural alterations. ${ }^{20}$ We hypothesized that under scenario 2 , the stochastic generation of $\operatorname{PrP}^{\mathrm{Sc}}$ in mutation carriers might engender neoantigens, which in turn might lead to protective humoral responses. Remarkably, however, we found no evidence of induction of humoral antibody-mediated immunity against $\operatorname{Pr} \mathrm{P}^{\mathrm{C}}$ by pathogenic $P R N P$ variants. Instead, our study suggests the prevalence of naturally occurring anti-PrP ${ }^{\mathrm{C}}$ antibodies in the general population independent of clinical signs of prion disease, PRNP variant, or PRNP p.129 polymorphism. Although reactivity to wild-type $\operatorname{PrP}$ has been reported in the serum of E219K homozygotes, ${ }^{10}$ and reactivity to a non-naturally occurring $\operatorname{PrP}$ peptide was reported in commercial $\mathrm{IgG},{ }^{9}$ the present report is to our knowledge the first observation of the PRNP genotype-independent presence of autoantibodies to full-length, wild-type PrP in
Table 4 Effect of PRNP codon 129 polymorphism and history of autoimmune disease on anti-PrPC autoantibody reactivity

\begin{tabular}{llll}
\hline Risk factor & $\begin{array}{l}\boldsymbol{\beta} \\
\text { coefficient }\end{array}$ & $\begin{array}{l}\text { 95\% confidence } \\
\text { interval }\end{array}$ & $\begin{array}{l}\boldsymbol{p} \\
\text { Value }\end{array}$ \\
\hline p.129MM & 0.83 & $0.63-1.10$ & 0.28 \\
\hline Crude & 0.88 & $0.67-1.15$ & 0.43 \\
\hline Adjusted & & & \\
\hline p.129MV & 1.23 & $0.94-1.62$ & 0.21 \\
\hline Crude & 1.13 & $0.86-1.48$ & 0.46 \\
\hline Adjusted & & & \\
\hline p.129VV & 0.88 & $0.49-1.56$ & 0.71 \\
\hline Crude & 1.04 & $0.59-1.83$ & 0.90 \\
\hline Adjusted & 1.18 & $0.44-3.15$ & 0.78 \\
\hline D178N/cis-129M & 1.09 & $0.37-3.22$ & 0.90 \\
\hline Crude & & & 0.76 \\
\hline Adjusted & 0.96 & $0.47-1.96$ & \\
\hline $\begin{array}{l}\text { History of autoimmune } \\
\text { disease }\end{array}$ & 1.12 & $0.55-2.26$ & \\
\hline Crude & & & \\
\hline Adjusted & & & \\
\hline
\end{tabular}

humans. Without disease-specific antibodies, one might speculate that PRNP mutations accumulate subclinical levels of prions to a point when clinical symptoms become evident.

In a subset of individuals, anti-PrP ${ }^{\mathrm{C}}$ autoantibody reactivity was tested in multiple blood drawings up to 1.5 years apart: the mean change of autoantibody titers was similar across $P R N P$ genotypes, in line with previous reports that showed stable autoantibody levels at least over several years. ${ }^{36,37}$

Matching in case-control studies is a controversial topic. ${ }^{38}$ In our study, initial analyses were performed on unmatched cohorts adjusted for known confounders of blood autoantibody levels; this approach was described to increase statistical power. ${ }^{39}$ To strengthen our arguments, we compared anti$\mathrm{PrP}^{\mathrm{C}}$ autoantibody levels in cases and matched controls. These results are in line with findings from the unmatched cohorts.

An increasing number of autoantibodies against neurodegenerative targets are being explored as biomarkers and as potential therapeutics. Naturally occurring autoantibodies against hyperphosphorylated tau protein have been isolated from several asymptomatic blood donors. ${ }^{40}$ Researchers from Neurimmune (Schlieren, Switzerland) recently reported the development of a fully human antibody against amyotrophic lateral sclerosis targeting pathologically misfolded SOD1, $\alpha$-miSOD1, from a memory B-cell library from healthy elderly 
individuals. ${ }^{41}$ Phase III trials involving aducanumab, a bona fide human antibody with potent $\beta$-amyloid clearing capabilities, were stopped prematurely. ${ }^{42}$

In previous works, we found that anti-PrP ${ }^{\mathrm{C}}$ antibodies can efficaciously counteract prions, ${ }^{6}$ a finding later confirmed by several other researchers. ${ }^{43}$ We speculated that anti-PrP ${ }^{C}$ autoantibodies from the general population could represent a reservoir of potential therapeutic agents against prion diseases. We find, however, that the distribution of titers appears similar between mutation carriers and controls, and between symptomatic and presymptomatic mutation carriers, arguing against the possibility that these autoantibodies are broadly beneficial. This is at variance with a previous preclinical report claiming neuroprotective effects for naturally occurring antibodies to a PrP peptide. ${ }^{9}$ Similarly, naturally occurring anti$\beta$-amyloid autoantibodies with neuroprotective effects were reported in mice, but did not meet primary cognitive endpoints when tested in a phase III clinical trial. ${ }^{44}$

Nonetheless, our work does not rule out the possibility of protective anti-PrP autoantibodies in the general population or in PRNP mutation carriers specifically. Our study was restricted to the assessment of autoantibody levels against fulllength, wild-type, recombinant human $\operatorname{PrP}^{\mathrm{C}}$. We $\operatorname{did}$ not evaluate the presence of antibodies specific to pathogenic PRNP mutations or to neoepitopes created by those mutations. Moreover, it is possible that humans develop antibodies specific to $\operatorname{Pr} \mathrm{P}^{\mathrm{Sc}}$, the aggregated form of the prion protein. In our experience, such anti-PrP $\mathrm{P}^{\mathrm{Sc}}$ antibodies tend to cross-react, at least to some level, with $\operatorname{PrP}^{\mathrm{C}}$. ${ }^{45}$ Another difficulty is that $\mathrm{PrP}^{\mathrm{Sc}}$ structure is very heterogenous in gPrDs: while brains from patients with genetic CJD and sCJD show similar patterns of $\operatorname{PrP}^{\mathrm{Sc}}, \operatorname{PrP}^{\mathrm{Sc}}$ is fragmented and of low molecular weight in brains from patients with GSS and can show marked variation in individuals with the D178N mutation. ${ }^{2,46}$ Future studies will focus on the detection of rare, low-titer anti-PrP $\mathrm{P}^{\mathrm{Sc}}$ antibodies, which may possess unique prion-clearing properties.

\section{Acknowledgment}

The authors thank the individuals who participated in this study, the participating patients, the patients' families, the CJD Foundation, referring clinicians, all the members of the National Prion Disease Pathology Surveillance Center for technical help, and Anne Kerschenmeyer, Tina Kottarathil, and Rita Moos at the University Hospital of Zurich for technical assistance.

\section{Study funding}

The authors received financial support from the EPSRC, BBSRC, ERC, and the Frances and Augustus Newman Foundation. This work was supported by the programs "Investissements d'avenir" ANR-10-IAIHU-06, "Santé Publique France," and grants from NIH (R01NS103848) and CDC (UR8/CCU515004). Collection of samples at Massachusetts General Hospital was funded by Prion
Alliance. The funders played no role in study design, data collection and analysis, decision to publish, or preparation of the manuscript.

\section{Disclosure}

K. Frontzek received an unrestricted grant by Ono Pharmaceuticals and was funded by the Theodor Ida Herzog-Egli Stiftung. M. Carta, M. Losa, and M. Epskamp report no disclosures. G. Meisl is funded by a Ramon Jenkins Research Fellowship at Sidney Sussex College. A. Anane, J.-P. Brandel, U. Camenisch, J. Castillas, and S. Hailk report no disclosures. T. Knowles received financial support by the EPSRC, BBSRC, ERC, and the Frances and Augustus Newman Foundation. E. Lindner was funded by the National Organization for Rare Diseases. A. Lutterotti reports no disclosures. E.V. Minikel has received research support in the form of charitable contributions from Charles River Laboratories and Ionis Pharmaceuticals and has consulted for Deerfield Management. I. Roiter, J.G. Safar, R. Sanchez-Valle, and D. Žáková report no disclosures. S. Hornemann is the recipient of grants from SystemsX.ch (SynucleiX) and the innovations commission of the University Hospital of Zurich. A. Aguzzi is the recipient of an Advanced Grant of the European Research Council (ERC 250356) and is supported by grants from the Swiss National Foundation (SNF, including a Sinergia grant), the Swiss Initiative in Systems Biology, SystemsX.ch (PrionX, SynucleiX), the Klinische Forschungsschwerpunkte (KFSPs) "small RNAs" and "Human Hemato-Lymphatic Diseases," and a Distinguished Investigator Award of the Nomis Foundation. Go to Neurology.org/N for full disclosures.

\section{Publication history}

Received by Neurology March 24, 2019. Accepted in final form December 4, 2019.

Appendix 1 Authors

\begin{tabular}{|c|c|c|}
\hline Name & Location & Contribution \\
\hline $\begin{array}{l}\text { Karl } \\
\text { Frontzek, } \\
\text { MD, PhD }\end{array}$ & $\begin{array}{l}\text { Institute of } \\
\text { Neuropathology, } \\
\text { University of Zurich, } \\
\text { Switzerland }\end{array}$ & $\begin{array}{l}\text { Conceptualization, data } \\
\text { curation, formal analysis, } \\
\text { funding acquisition, } \\
\text { investigation, } \\
\text { methodology, project } \\
\text { administration, software, } \\
\text { supervision, validation, } \\
\text { visualization, writing of } \\
\text { original draft }\end{array}$ \\
\hline $\begin{array}{l}\text { Manfredi } \\
\text { Carta, MD }\end{array}$ & $\begin{array}{l}\text { Institute of } \\
\text { Neuropathology, } \\
\text { University of Zurich, } \\
\text { Switzerland }\end{array}$ & $\begin{array}{l}\text { Investigation, validation, } \\
\text { writing of original draft }\end{array}$ \\
\hline $\begin{array}{l}\text { Marco Losa, } \\
\text { MD }\end{array}$ & $\begin{array}{l}\text { Institute of } \\
\text { Neuropathology, } \\
\text { University of Zurich, } \\
\text { Switzerland }\end{array}$ & $\begin{array}{l}\text { Investigation, validation, } \\
\text { writing of original draft }\end{array}$ \\
\hline $\begin{array}{l}\text { Mirka } \\
\text { Epskamp, } \\
\text { MSc }\end{array}$ & $\begin{array}{l}\text { Institute of } \\
\text { Neuropathology, } \\
\text { University of Zurich, } \\
\text { Switzerland }\end{array}$ & $\begin{array}{l}\text { Investigation, } \\
\text { methodology, validation, } \\
\text { writing of original draft }\end{array}$ \\
\hline
\end{tabular}


Appendix 1 (continued)

\begin{tabular}{|c|c|c|}
\hline Name & Location & Contribution \\
\hline $\begin{array}{l}\text { Georg Meisl, } \\
\text { PhD }\end{array}$ & $\begin{array}{l}\text { Department of Chemistry, } \\
\text { University of Cambridge, } \\
\text { UK }\end{array}$ & $\begin{array}{l}\text { Data curation, formal } \\
\text { analysis, software, writing } \\
\text { of original draft }\end{array}$ \\
\hline $\begin{array}{l}\text { Alice Anane, } \\
\text { ND }\end{array}$ & CJD Foundation Israel & $\begin{array}{l}\text { Data curation, } \\
\text { investigation, resources }\end{array}$ \\
\hline $\begin{array}{l}\text { Jean-Philippe } \\
\text { Brandel, MD }\end{array}$ & $\begin{array}{l}\text { Sorbonne University, Paris, } \\
\text { France }\end{array}$ & $\begin{array}{l}\text { Data curation, } \\
\text { investigation, resources }\end{array}$ \\
\hline $\begin{array}{l}\text { Ulrike } \\
\text { Camenisch, } \\
\text { PhD }\end{array}$ & $\begin{array}{l}\text { Institute of Surgical } \\
\text { Pathology, University of } \\
\text { Zurich, Switzerland }\end{array}$ & $\begin{array}{l}\text { Methodology, resources, } \\
\text { manuscript writing, } \\
\text { review, and editing }\end{array}$ \\
\hline $\begin{array}{l}\text { Joaquín } \\
\text { Castilla, PhD }\end{array}$ & $\begin{array}{l}\text { CIC bioGUNE and } \\
\text { IKERBASQUE, Basque } \\
\text { Foundation for Science, } \\
\text { Bizkaia, Spain }\end{array}$ & $\begin{array}{l}\text { Data curation, } \\
\text { investigation, resources }\end{array}$ \\
\hline $\begin{array}{l}\text { Stéphane } \\
\text { Haïk, MD, } \\
\text { PhD }\end{array}$ & $\begin{array}{l}\text { Sorbonne University, Paris, } \\
\text { France }\end{array}$ & $\begin{array}{l}\text { Data curation, } \\
\text { investigation, resources }\end{array}$ \\
\hline $\begin{array}{l}\text { Tuomas } \\
\text { Knowles, } \\
\text { PhD }\end{array}$ & $\begin{array}{l}\text { Department of Chemistry, } \\
\text { University of Cambridge, } \\
\text { UK }\end{array}$ & $\begin{array}{l}\text { Data curation, formal } \\
\text { analysis, software, } \\
\text { manuscript writing, } \\
\text { review, and editing }\end{array}$ \\
\hline $\begin{array}{l}\text { Ewald } \\
\text { Lindner, MD }\end{array}$ & $\begin{array}{l}\text { Ophthalmology Division, } \\
\text { University of Graz, Austria }\end{array}$ & $\begin{array}{l}\text { Data curation, } \\
\text { investigation, resources }\end{array}$ \\
\hline $\begin{array}{l}\text { Andreas } \\
\text { Lutterotti, } \\
\text { MD }\end{array}$ & $\begin{array}{l}\text { Department of Neurology, } \\
\text { Neuroimmunology and } \\
\text { MS Research (NIMS), } \\
\text { University of Zurich, } \\
\text { Switzerland }\end{array}$ & $\begin{array}{l}\text { Methodology, manuscript } \\
\text { writing, review, and } \\
\text { editing }\end{array}$ \\
\hline $\begin{array}{l}\text { Eric Vallabh } \\
\text { Minikel, PhD }\end{array}$ & $\begin{array}{l}\text { Broad Institute, } \\
\text { Cambridge, MA }\end{array}$ & $\begin{array}{l}\text { Data curation, } \\
\text { investigation, resources, } \\
\text { manuscript writing, } \\
\text { review, and editing }\end{array}$ \\
\hline $\begin{array}{l}\text { Ignazio } \\
\text { Roiter, MD }\end{array}$ & Treviso Hospital, Italy & $\begin{array}{l}\text { Data curation, } \\
\text { investigation, resources }\end{array}$ \\
\hline $\begin{array}{l}\text { Jiri G. Safar, } \\
\text { MD }\end{array}$ & $\begin{array}{l}\text { Department of Pathology, } \\
\text { Neurology, and National } \\
\text { Prion Disease Pathology } \\
\text { Surveillance Center, Case } \\
\text { Western Reserve } \\
\text { University, Cleveland, OH }\end{array}$ & $\begin{array}{l}\text { Data curation, } \\
\text { investigation, resources }\end{array}$ \\
\hline $\begin{array}{l}\text { Raquel } \\
\text { Sanchez- } \\
\text { Valle, MD, } \\
\text { PhD }\end{array}$ & $\begin{array}{l}\text { Alzheimer's Disease and } \\
\text { Other Cognitive Disorders } \\
\text { Unit, Hospital Clinic, } \\
\text { IDIBAPS, University of } \\
\text { Barcelona, Spain }\end{array}$ & $\begin{array}{l}\text { Data curation, } \\
\text { investigation, resources }\end{array}$ \\
\hline $\begin{array}{l}\text { Ďana } \\
\text { Źáková, PhD }\end{array}$ & $\begin{array}{l}\text { Department of Prion } \\
\text { Diseases, Slovak Medical } \\
\text { University, Bratislava, } \\
\text { Slovakia }\end{array}$ & $\begin{array}{l}\text { Data curation, } \\
\text { investigation, resources }\end{array}$ \\
\hline $\begin{array}{l}\text { Simone } \\
\text { Hornemann, } \\
\text { PhD }\end{array}$ & $\begin{array}{l}\text { Institute of } \\
\text { Neuropathology, } \\
\text { University of Zurich, } \\
\text { Switzerland }\end{array}$ & $\begin{array}{l}\text { Conceptualization, } \\
\text { supervision, writing of } \\
\text { original draft }\end{array}$ \\
\hline $\begin{array}{l}\text { Adriano } \\
\text { Aguzzi, MD, } \\
\text { PhD }\end{array}$ & $\begin{array}{l}\text { Institute of } \\
\text { Neuropathology, } \\
\text { University of Zurich, } \\
\text { Switzerland }\end{array}$ & $\begin{array}{l}\text { Conceptualization, } \\
\text { funding acquisition, } \\
\text { methodology, project } \\
\text { administration, resources, } \\
\text { supervision, writing of } \\
\text { original draft }\end{array}$ \\
\hline
\end{tabular}

Appendix 2 Coinvestigators

\begin{tabular}{|c|c|c|c|}
\hline Name & Location & Role & Contribution \\
\hline $\begin{array}{l}\text { Marc L. } \\
\text { Cohen }\end{array}$ & $\begin{array}{l}\text { Department of } \\
\text { Pathology and } \\
\text { National Prion } \\
\text { Disease Pathology } \\
\text { Surveillance } \\
\text { Center, Case } \\
\text { Western Reserve } \\
\text { University, } \\
\text { Cleveland, OH }\end{array}$ & $\begin{array}{l}\text { Center } \\
\text { codirector }\end{array}$ & $\begin{array}{l}\text { Diagnostic } \\
\text { neuropathology }\end{array}$ \\
\hline $\begin{array}{l}\text { Hasier } \\
\text { Eraña, PhD }\end{array}$ & $\begin{array}{l}\text { Atlas Molecular } \\
\text { Pharma SL, Derio, } \\
\text { Bizkaia, Spain }\end{array}$ & $\begin{array}{l}\text { Head of } \\
\text { project: } \\
\text { prion } \\
\text { diseases }\end{array}$ & $\begin{array}{l}\text { Laboratory } \\
\text { research } \\
\text { responsible for } \\
\text { blood sample } \\
\text { extraction from } \\
\text { patients/families } \\
\text { with a genetic prion } \\
\text { disease }\end{array}$ \\
\hline $\begin{array}{l}\text { Sonia M. } \\
\text { Vallabh, JD }\end{array}$ & $\begin{array}{l}\text { Broad Institute, } \\
\text { Cambridge, MA }\end{array}$ & $\begin{array}{l}\text { Site } \\
\text { investigator }\end{array}$ & $\begin{array}{l}\text { Provided samples } \\
\text { and clinical data }\end{array}$ \\
\hline $\begin{array}{l}\text { Chloe } \\
\text { Nobuhara, } \\
\text { BS }\end{array}$ & $\begin{array}{l}\text { Massachusetts } \\
\text { General Hospital, } \\
\text { Boston }\end{array}$ & $\begin{array}{l}\text { Site } \\
\text { coordinator }\end{array}$ & $\begin{array}{l}\text { Provided samples } \\
\text { and clinical data }\end{array}$ \\
\hline $\begin{array}{l}\text { Chase } \\
\text { Wennick, } \\
\text { BS }\end{array}$ & $\begin{array}{l}\text { Massachusetts } \\
\text { General Hospital, } \\
\text { Boston }\end{array}$ & $\begin{array}{l}\text { Site } \\
\text { coordinator }\end{array}$ & $\begin{array}{l}\text { Provided samples } \\
\text { and clinical data }\end{array}$ \\
\hline $\begin{array}{l}\text { Steven E. } \\
\text { Arnold, MD }\end{array}$ & $\begin{array}{l}\text { Massachusetts } \\
\text { General Hospital, } \\
\text { Boston }\end{array}$ & $\begin{array}{l}\text { Site } \\
\text { investigator }\end{array}$ & $\begin{array}{l}\text { Provided samples } \\
\text { and clinical data }\end{array}$ \\
\hline $\begin{array}{l}\text { Gianluigi } \\
\text { Forloni, } \\
\text { PhD }\end{array}$ & $\begin{array}{l}\text { Mario Negri } \\
\text { Institute for } \\
\text { Pharmacologic } \\
\text { Research, Italy }\end{array}$ & $\begin{array}{l}\text { Department } \\
\text { head }\end{array}$ & $\begin{array}{l}\text { Provided samples } \\
\text { and clinical data }\end{array}$ \\
\hline
\end{tabular}

\section{References}

1. Aguzzi A, Lakkaraju AKK, Frontzek K. Toward therapy of human prion diseases. Annu Rev Pharmacol Toxicol 2018;58:331-351.

2. Kim MO, Takada LT, Wong K, Forner SA, Geschwind MD. Genetic PrP prion diseases. Cold Spring Harbor Perspect Biol 2018;10:pii: a033134.

3. Will RG, Ironside JW. Sporadic and infectious human prion diseases. Cold Spring Harb Perspect Med 2017;7:pii: a024364.

4. Minikel EV, Vallabh SM, Orseth MC, et al. Age at onset in genetic prion disease and the design of preventive clinical trials. Neurology 2019;93:e125-e134.

5. Scheckel C, Aguzzi A. Prions, prionoids and protein misfolding disorders. Nat Rev Genet 2018;19:405-418.

6. Heppner FL, Musahl C, Arrighi I, et al. Prevention of scrapie pathogenesis by transgenic expression of anti-prion protein antibodies. Science 2001;294:178-182.

7. Sonati T, Reimann RR, Falsig J, et al. The toxicity of antiprion antibodies is mediated by the flexible tail of the prion protein. Nature 2013;501:102-106.

8. Herrmann US, Sonati T, Falsig J, et al. Prion infections and anti-PrP antibodies trigger converging neurotoxic pathways. PLoS Pathog 2015;11:e1004662.

9. Wei X, Roettger $Y$, Tan B, et al. Human anti-prion antibodies block prion peptide fibril formation and neurotoxicity. J Biol Chem 2012;287:12858-12866.

10. Omae $\mathrm{Y}$, Ito $\mathrm{S}$, Takeuchi $\mathrm{M}$, et al. Integrative genome analysis identified the KANNO blood group antigen as prion protein. Transfusion 2019;59:2429-2435.

11. Haik S, Marcon G, Mallet A, et al. Doxycycline in Creutzfeldt-Jakob disease: a phase 2, randomised, double-blind, placebo-controlled trial. Lancet Neurol 2014;13:150-158.

12. Haik S, Brandel JP, Salomon D, et al. Compassionate use of quinacrine in CreutzfeldtJakob disease fails to show significant effects. Neurology 2004;63:2413-2415.

13. Collinge J, Gorham M, Hudson F, et al. Safety and efficacy of quinacrine in human prion disease (PRION-1 study): a patient-preference trial. Lancet Neurol 2009;8: 334-344.

14. Otto M, Cepek L, Ratzka P, et al. Efficacy of flupirtine on cognitive function in patients with CJD: a double-blind study. Neurology 2004;62:714-718.

15. Killworth $\mathrm{H}$. Fourth patient to be given innovative treatment for CJD [online]. Available at: ucl.ac.uk/news/2019/jan/fourth-patient-be-given-innovative-treatmentcjd. Accessed September 13, 2019. 
16. Reimann RR, Aguzzi A. Intrinsic toxicity of antibodies to the globular domain of the prion protein. Biol Psychiatry 2018;84:e51-e52.

17. Reimann RR, Sonati T, Hornemann S, et al. Differential toxicity of antibodies to the prion protein. PLoS Pathog 2016;12:e1005401.

18. Wu B, McDonald AJ, Markham $\mathrm{K}$, et al. The $\mathrm{N}$-terminus of the prion protein is a toxic effector regulated by the C-terminus. Elife 2017;6:pii: e23473.

19. Minikel EV, Vallabh SM, Lek M, et al. Quantifying prion disease penetrance using large population control cohorts. Sci Transl Med 2016;8:322ra329.

20. Biljan I, Ilc G, Plavec J. Understanding the effect of disease-related mutations on human prion protein structure: insights from NMR spectroscopy. Prog Mol Biol Transl Sci 2017;150:83-103.

21. WHO Manual for Surveillance of Human Transmissible Spongiform Encephalopathies, Including Variant Creutzfeldt-Jakob Disease. Geneva: World Health Organization; 2003.

22. Ironside JW, Ritchie DL, Head MW. Prion diseases. Handb Clin Neurol 2017;145: 393-403.

23. Hill JT, Demarest BL, Bisgrove BW, Su YC, Smith M, Yost HJ. Poly peak parser: method and software for identification of unknown indels using sanger sequencing of polymerase chain reaction products. Dev Dyn 2014;243:1632-1636.

24. Wright ES. Using DECIPHER v2.0 to analyze big biological sequence data in R. R J 2016;8:352-359.

25. Huber W, Carey VJ, Gentleman R, et al. Orchestrating high-throughput genomic analysis with Bioconductor. Nat Methods 2015;12:115-121.

26. Watad A, Bragazzi NL, Adawi M, et al. Autoimmunity in the elderly: insights from basic science and clinics: a mini-review. Gerontology 2017;63:515-523.

27. Ngo ST, Steyn FJ, McCombe PA. Gender differences in autoimmune disease. Front Neuroendocrinol 2014;35:347-369.

28. Kifude CM, Rajasekariah HG, Sullivan DJ Jr, et al. Enzyme-linked immunosorbent assay for detection of Plasmodium falciparum histidine-rich protein 2 in blood, plasma, and serum. Clin Vaccin Immunol 2008;15:1012-1018.

29. Bursac Z, Gauss CH, Williams DK, Hosmer DW. Purposeful selection of variables in logistic regression. Source Code Biol Med 2008;3:17.

30. Hess RD. Routine Epstein-Barr virus diagnostics from the laboratory perspective: still challenging after 35 years. J Clin Microbiol 2004;42:3381-3387.

31. Zerr I, Bodemer M, Gefeller O, et al. Detection of 14-3-3 protein in the cerebrospinal fluid supports the diagnosis of Creutzfeldt-Jakob disease. Ann Neurol 1998;43:32-40.
32. Kobayashi A, Teruya K, Matsuura Y, et al. The influence of PRNP polymorphisms on human prion disease susceptibility: an update. Acta Neuropathol 2015;130:159-170.

33. Sun L, Li X, Lin X, Yan F, Chen K, Xiao S. Familial fatal insomnia with atypical clinical features in a patient with D178N mutation and homozygosity for Met at codon 129 of the prion protein gene. Prion 2015;9:228-235.

34. Chen S, He S, Shi XH, et al. The clinical features in Chinese patients with PRNP D178N mutation. Acta Neurol Scand 2018;138:151-155.

35. Matusiewicz A, Strozynska-Byrska J, Olesinska M. Polyautoimmunity in rheumatological conditions. Int J Rheum Dis 2019;22:386-391.

36. Nagele EP, Han M, Acharya NK, DeMarshall C, Kosciuk MC, Nagele RG. Natural IgG autoantibodies are abundant and ubiquitous in human sera, and their number is influenced by age, gender, and disease. PLoS One 2013;8:e60726.

37. Lacroix-Desmazes S, Mouthon L, Kaveri SV, Kazatchkine MD, Weksler ME. Stability of natural self-reactive antibody repertoires during aging. J Clin Immunol 1999;19: 26-34.

38. Mansournia MA, Jewell NP, Greenland S. Case-control matching: effects, misconceptions, and recommendations. Eur J Epidemiol 2018;33:5-14.

39. Faresjo T, Faresjo A. To match or not to match in epidemiological studies: same outcome but less power. Int J Environ Res Public Health 2010;7:325-332.

40. Pascual G, Wadia JS, Zhu X, et al. Immunological memory to hyperphosphorylated tau in asymptomatic individuals. Acta Neuropathol 2017;133:767-783.

41. Maier M, Welt T, Wirth F, et al. A human-derived antibody targets misfolded SOD and ameliorates motor symptoms in mouse models of amyotrophic lateral sclerosis. Sci Transl Med 2018;10.

42. Selkoe DJ. Alzheimer disease and aducanumab: adjusting our approach. Nat Rev Neurol 2019; 15:365-366

43. White AR, Enever P, Tayebi M, et al. Monoclonal antibodies inhibit prion replication and delay the development of prion disease. Nature 2003;422:80-83.

44. Relkin NR, Thomas RG, Rissman RA, et al. A phase 3 trial of IV immunoglobulin for Alzheimer disease. Neurology 2017;88:1768-1775.

45. Polymenidou M, Stoeck K, Glatzel M, Vey M, Bellon A, Aguzzi A. Coexistence of multiple PrPSc types in individuals with Creutzfeldt-Jakob disease. Lancet Neurol 2005;4:805-814.

46. Haik S, Peoc'h K, Brandel JP, et al. Striking PrPsc heterogeneity in inherited prion diseases with the D178N mutation. Ann Neurol 2004;56:909-910; author reply 910-911. 


\section{Neurology}

Autoantibodies against the prion protein in individuals with $P R N P$ mutations Karl Frontzek, Manfredi Carta, Marco Losa, et al.

Neurology 2020;95;e2028-e2037 Published Online before print February 25, 2020

DOI 10.1212/WNL.0000000000009183

This information is current as of February 25, 2020

$\begin{array}{ll}\begin{array}{l}\text { Updated Information \& } \\ \text { Services }\end{array} & \begin{array}{l}\text { including high resolution figures, can be found at: } \\ \text { http://n.neurology.org/content/95/14/e2028.full }\end{array} \\ \text { References } & \text { This article cites } 43 \text { articles, } 7 \text { of which you can access for free at: } \\ \text { http://n.neurology.org/content/95/14/e2028.full\#ref-list-1 } & \text { This article, along with others on similar topics, appears in the } \\ \text { following collection(s): } & \text { All CBMRT/Null Hypothesis } \\ \text { http://n.neurology.org/cgi/collection/all_cbmrt_null_hypothesis } \\ \text { Autoimmune diseases } \\ \text { http://n.neurology.org/cgi/collection/autoimmune_diseases } \\ \text { Prion } \\ \text { http://n.neurology.org/cgi/collection/prion } \\ \text { Information about reproducing this article in parts (figures,tables) or in } \\ \text { its entirety can be found online at: } \\ \text { http://www.neurology.org/about/about_the_journal\#permissions } \\ \text { Information about ordering reprints can be found online: } \\ \text { http://n.neurology.org/subscribers/advertise }\end{array}$

Neurology ${ }^{\circledR}$ is the official journal of the American Academy of Neurology. Published continuously since 1951 , it is now a weekly with 48 issues per year. Copyright (C) 2020 American Academy of Neurology. All rights reserved. Print ISSN: 0028-3878. Online ISSN: 1526-632X.

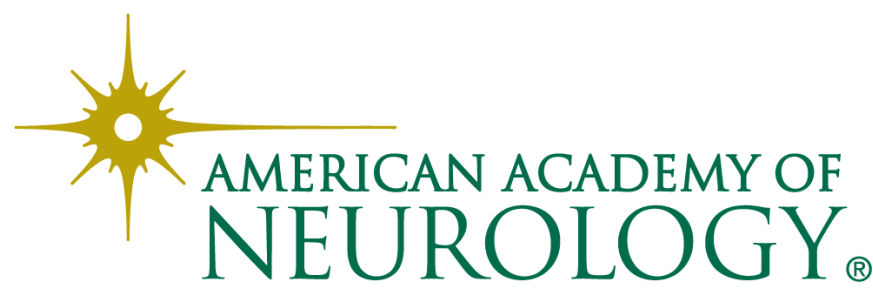

